\title{
Analysis of Mechanical, Microstructural Properties and Weld Morphology of A-TIG Welded AH-36 Marine-Grade Steels with Oxide and Duplex Flux Coating
}

\author{
K. Vijaya Kumar ${ }^{1}$, N. Ramanaiah² and N. Bhargava Rama Mohan Rao ${ }^{3}$ \\ ${ }^{1}$ Faculty of Mechanical Engineering, GITAM University, Visakhapatnam 530040, India \\ Phone: +919652805628 \\ 2Faculty of Mechanical Engineering, Andhra University College of Engineering, Andhra University, Visakhapatnam 530022, India \\ ${ }^{3}$ Faculty of Metallurgical Engineering, Andhra University College of Engineering, Andhra University, Visakhapatnam 530022, India
}

\begin{abstract}
The current study investigates the metallurgical, mechanical properties and weld morphology of AH36 marine grade steel (with a thickness of $8 \mathrm{~mm}$ ) by activated-tungsten inert gas (A-TIG) butt joints, with the application of different fluxes $\left(\mathrm{MoO}_{3}, \mathrm{~V}_{2} \mathrm{O}_{5}\right.$, and duplex of $\mathrm{MoO}_{3}$ and $\mathrm{V}_{2} \mathrm{O}_{5}$ ) at various process parameters. The welding speed was kept constant at $120 \mathrm{~mm} / \mathrm{min}$, and current varied from $160 \mathrm{~A}$ to $220 \mathrm{~A}$ uniformly to optimise process parameters to achieve desired mechanical properties, weld morphology, and lowest possible heat input. The study also focused on comparing tensile strength, impact strength, and microhardness, heat input during welding, weld bead depth and width between conventional TIG welding and activated flux TIG welding processes at various operation parameters. Tensile results reported that fracture occurs at the base region in ordinary TIG welding and the activated tungsten inert gas welding process. It was noticed that a higher depth to width ratio attained $\mathrm{MoO}_{3}$ and $\mathrm{V}_{2} \mathrm{O}_{5}$ duplex flux coated weldments. There is evidence that the depth of weld joints is enhanced because of stable arc, Marangoni effect, and arc constriction. Microhardness results reported that the fusion zone has a higher microhardness in the activated tungsten inert gas welding than the ordinary TIG welding. It was concluded that out of all fluxes, $\mathrm{MoO}_{3}$ and $\mathrm{V}_{2} \mathrm{O}_{5}$ duplex flux coating produce better butt welds of $\mathrm{AH} 36$ steel.
\end{abstract}

ARTICLE HISTORY

Received: $13^{\text {th }}$ Nov 2020

Revised: $9^{\text {th }}$ Sept 2021

Accepted: 24 ${ }^{\text {th }}$ Sept 2021

\section{KEYWORDS}

A-TIG Welding;

AH36 steel;

Weld bead depth;

Weld bead width;

Weld zones

\section{INTRODUCTION}

The shipbuilding, seaward, and structural based components utilised high strength low alloy steels (HSLA) for manufacturing parts. One of the most generally used HSLA for shipbuilding is AH36 steel. The steel exhibits an equiaxed very fine-grain ferrite microstructure accompanied by excellent weldability and its tensile property. Most of these kinds of steel comprise $\mathrm{Fe}$ with roughly $0.2 \% \mathrm{C}$ and grain refining elements such as $\mathrm{Ca}, \mathrm{Zr}$, and $\mathrm{Sn}$. These provide upgraded protection from the weak crack and other required quality levels of steel obtained from other alloying elements like $\mathrm{Si}$, $\mathrm{Nb}, \mathrm{Mn}$, and Mo. The American Bureau of Shipping utilised AH36 steel to manufacture transportation goods, vessels, and structural components because of its versatility characteristics [1],[2]. Tungsten Inert Gas (TIG) welding is a dependable method of welding various pure metals and alloy components to guarantee the predominant nearly high quality of weld without defect. During TIG welding, the tungsten electrode, electric arc, and molten metal had been protected by shielded gas of argon or helium. It became the mainstream approach of electrical arc welding when topnotched welds were required. TIG commonly used welding of bars, plates, cylinders, and extra-large castings to be used in naval, marine, space engineering, research, ship construction, and the entire production. TIG welding worked utilising filler rods to create deep area weld joints. Autogenously welded components without filler rods could be applicable for thin sections. The TIG welding technique vital constraint was less efficient because of its lower generative capacity price and shallow weld joint depth. Furthermore, the TIG welding process's powerlessness became restricted to weld joints depth up to $3 \mathrm{~mm}$ only [3],[4].

Although the TIG welding method's capability issues lie withinside the constrained depth of weld joints, which might weld in one pass, fewer tolerances of few fabric compositions, and less production capability. There will be a possibility that modern welding strategies were applied to improvise the depth of weld joints, and weld quality will become excessively large in such a way that corresponds in size and benefits in the depth of weld joint [5]. Developments and approaches have been initiated for deep weld joints in lots of electric arc-welding processes. The most used and top-notch strategies have been using activated flux with TIG (A-TIG) welding method. The A-TIG technique enhanced the weld depth and became the first approach by Paton Electric Welding Institute within the 1960s [6],[7]. The inorganic compounds of oxides fluxes, including fluorides and chlorides, were used as an activated flux. These were combined with acetone applied on the weld surface earlier than the welding in a small layer with a paintbrush [8],[9]. In the A-TIG welding, weld depth compared to traditional TIG welding enhances the weld depth thickness from $6 \mathrm{~mm}$ to $10 \mathrm{~mm}$ for stainless steel in a single pass [9],[10]. The exploitation of the A-TIG welding method results in a 200-300\% enhancement in weld depth capability [11],[12]. As a result of that diminishing weld time and lower the cost of manufacturing. 
Further to that, in Chern et al. [13], $\mathrm{SiO}_{2}, \mathrm{MoO}_{3}$, and $\mathrm{Cr}_{2} \mathrm{O}_{3}$ flux coatings significantly impact excessive weld depth penetration capability on steels. On the flip side, they also improved the tensile strength of the stainless-steel welds compared to the traditional TIG welds and compared various fluxes and concluded that their effect considerable full weld depth and weld joint strength of duplex stainless-steel 2205. Then again, the researchers also studied that $\mathrm{SiO}_{2}$ flux coating in A-TIG welding achieved better weld depth and joint strength. In addition to that $\mathrm{TiO}_{2} \mathrm{flux}_{\text {layer shows excessive arc }}$ constriction. Devendranath et al. [14] concluded that diverse dissimilar joints super-duplex stainless steel and primary solid solution stainless steel had been the evidence of better A-TIG welded joints with $\mathrm{SiO}_{2}$ flux coat. The researchers also documented that the utilisation of flux coating in the welding increases the tensile strength of the welds compared to the AISI 316L workpiece material.

Tseng and Hsu [15] concluded that development within the weld joint depth and a reduction in weld joint width while using $\mathrm{SiO}_{2}$ and $\mathrm{MoO}_{3}$ flux coatings throughout the welding of AISI316L. Venkatesan et al. [16] conclude using multiple fluxes, i.e., $75-90 \%$ of $\mathrm{SiO}_{2}$ and $\mathrm{TiO}_{2}$, results in a higher depth of weld than single layer A-TIG welding. Furthermore, in Huang et al. [17], using $\mathrm{MnO}_{2}-\mathrm{ZnO}$ mixed flux preserved $\delta$-ferrite primary solid solution and hot cracking responsiveness. Finally, whichever attempt made in A-TIG welding results in weld depth penetration, joint strength, and significant production cost savings. The primary limits for employing GTAW for thick plates are shallow penetration, minimal dilution, and a poor deposition rate in a single pass [18].

According to the literature review findings, utilising activated flux can improve penetration depth and creep rupture life. Mechanical properties improved significantly, and productivity increased as well [19]. The ability of the response surface approach and genetic algorithm technique to forecast the effect of variable parameters on replies has been discovered by Nagaraju et al. [20]. In ternary fluxes, however, statistical programs are utilised to design a formulation based on the percentages of flux components to improve weld depth and mechanical qualities [21]. When comparing the width of the bead on the plate, A-TIG welding creates narrower welds than traditional TIG welding. Full penetration was obtained only with A-TIG welding at $200 \mathrm{~A}$ and $7.8 \mathrm{~cm} / \mathrm{min}$ speed [22]. The tensile strength of ATIG welds is higher than that of TIG or parent metal welds $(618 \mathrm{MPa})$. This is related to the development of delta ferrite, which has extremely high mechanical properties [23]. The mechanical properties of the weld produced with the fluxes were researched. Flux powder was designed for welding of DMR-249A shipbuilding steel [24]. The activated-flux TIG welding process, which uses welding flux to minimise bead width and promote weld penetration, is the technology that has gotten the most attention. One way often used to improve the industrial efficiency and penetrating ability of the TIG welding process is activating flux with the welding process [25]. Compared to multi-pass GTAW of various steels, welding performed by the A-TIG welding technology may have good mechanical qualities [26]. Because of the heat created, oxygen-based flux governs dendritic arm spacing and length, which the oxygen level can regulate in the weld. In the case of A-TIG welding with $\mathrm{SiO}_{2}$ and $\mathrm{CrO}_{3}$ flux, higher oxygen concentration with higher heat generation dominates bigger grain size, long dendrite length, and longer dendritic arm spacing [27]. Nineteen compositions were made from three oxides $\left(\mathrm{TiO}_{2}, \mathrm{MoO}_{3}\right.$, and $\mathrm{SiO}_{2}$ ) using the simplex lattice degree four design, with the best result being $55 \% \mathrm{TiO}_{2}+45 \% \mathrm{MoO}$. In comparison to standard TIG weld beads, the enhanced formula's depth weld was doubled (7.24 mm, $3.64 \mathrm{~mm})$ [28]. Because of Marangoni convection and arc constriction mechanisms, the A-TIG welding approach achieved maximum penetration utilising $\mathrm{MoO}_{3}$ flux, which is $107 \%$ greater than a standard TIG-welded sample. The $\mathrm{MgO}, \mathrm{SiO}_{2}, \mathrm{CaF}_{2}, \mathrm{and} \mathrm{MgCl}_{2} \times 6 \mathrm{H}_{2} \mathrm{O}$ also demonstrated a significant increase in weld penetration [29].

The overall goal of this project is to A-TIG welding of AH-36 marine-grade steel and investigate relevant weld morphology, as well as mechanical properties of the A-TIG welded joints, such as tensile strength, microhardness, and impact strength experimentally. A parametric study has been conducted to predict optimum heat input that certainly yields maximum tensile strength, impact strength and microhardness of weld joints. In addition to this comparison of TIG and A-TIG weldments, various fluxes such as $\mathrm{MoO}_{3}, \mathrm{~V}_{2} \mathrm{O}_{5}$ and duplex of both were used. The cost practical, time matters and durability of weld joints for the application of shipbuilding and other marine-related have been studied, and relevant results are presented in the following sections.

\section{MATERIALS AND EXPERIMENTAL DETAILS}

In the current research, AH-36 steel material was used to perform TIG and A-TIG weldments. The chemical constitution of the workpiece material has been investigated utilising the dry spectroscopic strategy. Table 1 and Table 2 show the chemical composition and mechanical properties of the workpiece material, respectively.

Table 1. Chemical constitution of AH36 steel material.

\begin{tabular}{lccccccc}
\hline Element & wt. $\%$ & Element & wt. $\%$ & Element & wt. $\%$ & Element & wt. $\%$ \\
\hline $\mathrm{C}$ & 0.206 & $\mathrm{Cu}$ & 0.0264 & $\mathrm{Co}$ & $<0.00150$ & $\mathrm{Ce}$ & $<0.00300$ \\
$\mathrm{Si}$ & 0.262 & $\mathrm{Nb}$ & $<0.00100$ & $\mathrm{Zn}$ & 0.00224 & $\mathrm{Sb}$ & $<0.00100$ \\
$\mathrm{Mn}$ & 0.794 & $\mathrm{~V}$ & 0.00061 & $\mathrm{~B}$ & $<0.00020$ & $\mathrm{Te}$ & $<0.00100$ \\
$\mathrm{P}$ & 0.00457 & $\mathrm{~W}$ & $<0.00100$ & $\mathrm{Al}$ & 0.0103 & $\mathrm{Fe}$ & 98.600 \\
$\mathrm{~S}$ & 0.0119 & $\mathrm{Ca}$ & 0.00169 & $\mathrm{Sn}$ & 0.00480 & & \\
$\mathrm{Cr}$ & 0.0521 & $\mathrm{la}$ & $<0.00100$ & $\mathrm{~Pb}$ & 0.00474 & & \\
$\mathrm{Ni}$ & 0.0102 & $\mathrm{Ti}$ & $<0.00100$ & $\mathrm{As}$ & 0.0202 & & \\
$\mathrm{Mo}$ & 0.00475 & $\mathrm{Zr}$ & $<0.00150$ & $\mathrm{Bi}$ & $<0.0040$ & & \\
\hline
\end{tabular}


Table 2. Base material mechanical properties.

\begin{tabular}{lc}
\hline Properties & Value \\
\hline Yield strength $0.2 \%$ & $289.36 \mathrm{MPa}$ \\
UTS & $453.63 \mathrm{MPa}$ \\
Young's modulus & $25.24 \mathrm{GPa}$ \\
\hline
\end{tabular}

\section{Experimental Procedure}

The workpiece material for this experiment was hot rolled $8 \mathrm{~mm}$ thick AH36 marine grade steel plates. In this experiment, the workpiece material was cut using the water jet machining (WJM) method into a rectangular shape with dimensions of $200 \times 75 \times 8 \mathrm{~mm}$. Figure 1 depicts the butt-weld configuration. To remove the surface contaminants, the $5 \mathrm{~mm}$ sections of the work surfaces were polished with surface grinder and cleaned with acetone correlates with no gap between workpieces. Oxide fluxes such as $\mathrm{MoO}_{3}$ and $\mathrm{V}_{2} \mathrm{O}_{5}$ were weighted according to the volume applied and then mixed with acetone in a tiny cup using a stirrer. During the process, the workpieces were positioned in the butt position on the worktable indicated in Figure 2. After the oxides-acetone mixer became like paste, it was applied to the worktop surfaces of plates with $5 \mathrm{~mm}$ width and $1 \mathrm{~mm}$ thick on each side. According to Ahmadi and Ebrahimi [30], the activated flux thickness has a significant impact on penetration depth. A tungsten thoriated electrode tip is fitted in a nozzle at $30^{\circ}$ angle diameter and a $3 \mathrm{~mm}$ diameter.

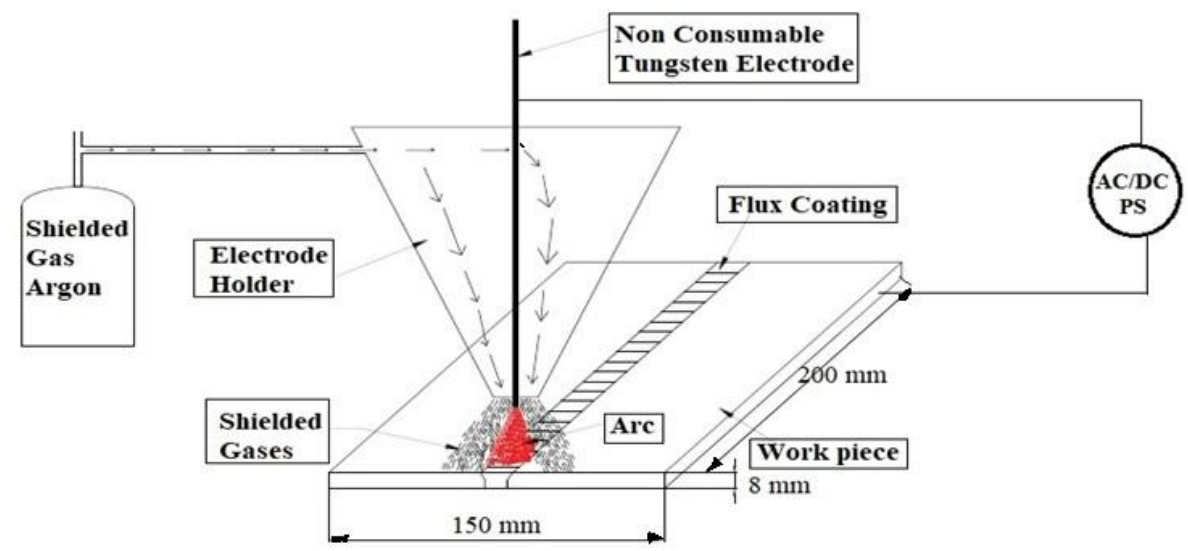

Figure 1. Schematic drawing of TIG Welding Unit

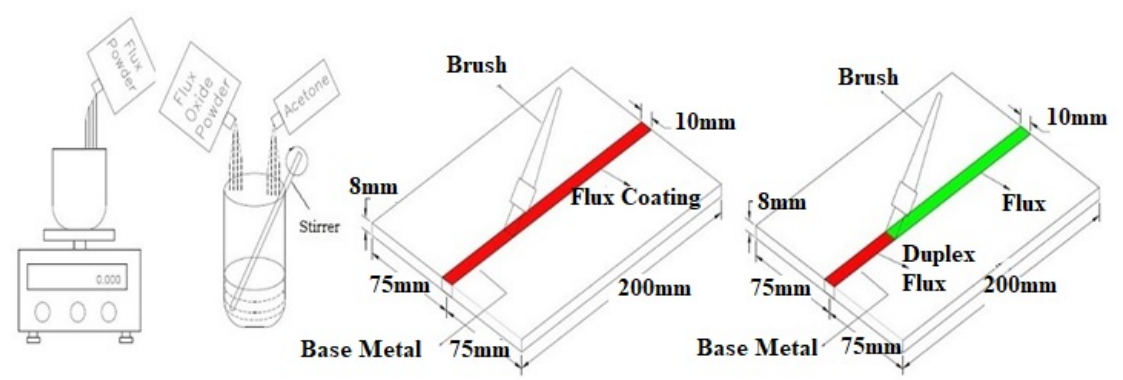

Figure 2. Illustration of A-TIG welding process.

Butt welding experiments were carried out utilising 3501x automatic TIG welding equipment and direct current straight polarity (DCSP) power sources. During the procedure, the arc between the tungsten electrode and the workpiece was constant, and the inert gas protected it (argon). The welding current and the voltage were consistently varied from 160 A to $220 \mathrm{~A}$, maintaining the welding speed at $120 \mathrm{~mm} / \mathrm{min}$. The butt weldments were sliced into various types of sections to conduct different mechanical testing using WJM. The weld joints tensile test specimen (in Figure 3) is according to ASTM E8/4M, tested on MAKE-M/S Instron (Model no: 8801 ) with a limit of $100 \mathrm{kN}$ at a crosshead speed of $2 \mathrm{~mm} / \mathrm{min}$, as shown in Figure 4. The hardness estimations and large-scale/miniature structure examinations were performed on samples with dimensions of $50 \times 15 \times 8 \mathrm{~mm}$. The welded samples were cut at a straight angle by keeping the weld zone in the middle. Furthermore, the Izod impact test machine is used to determine the impact strength. The samples were cut into Izod test specifications of $50 \times 10 \times 8 \mathrm{~mm}$ with a notch at the centre.

\section{Microhardness}

Microhardness measurements of TIG and A-TIG weldments were using Shimadzu hardness equipment G20. The maximum capacity of this equipment was $2 \mathrm{~kg}$, and hardness values were directly measured by the length of the diagonals. It had microscopes of $10 \times$ and $40 \times$ resolution so that it could measure the length of the diagonals. The Vickers hardness (HV) was calculated using Eq. (1). 


$$
V H N=1.854 \frac{P}{d^{2}}
$$

where the load $P$ is in gf, and the mean diagonal $d$ is in $\mu \mathrm{m}$. This created hardness number units of gf $/ \mu \mathrm{m}^{2} \mathrm{despite}$ the fact that the equivalent units $\mathrm{kgf} / \mathrm{mm}^{2}$ were chosen. The indentation tests can be performed on the specimen at different loads with different holding times. The holding times are used to test the dependency of the material on rate-dependent plasticity.

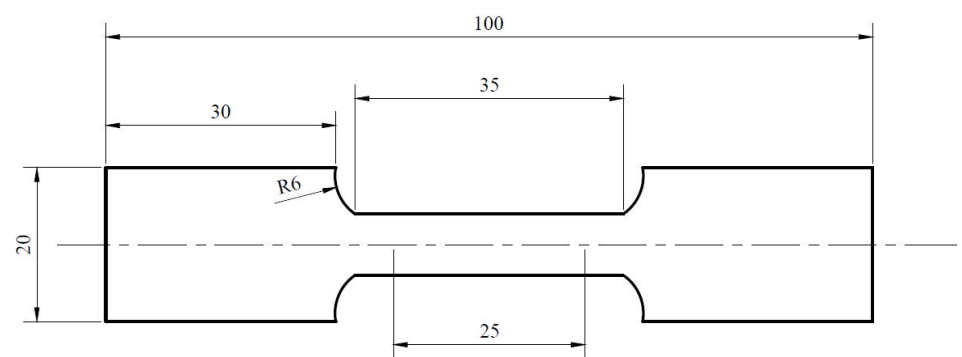

Figure 3. Tensile test dimensions (in mm) as per ASTM E8M-04.

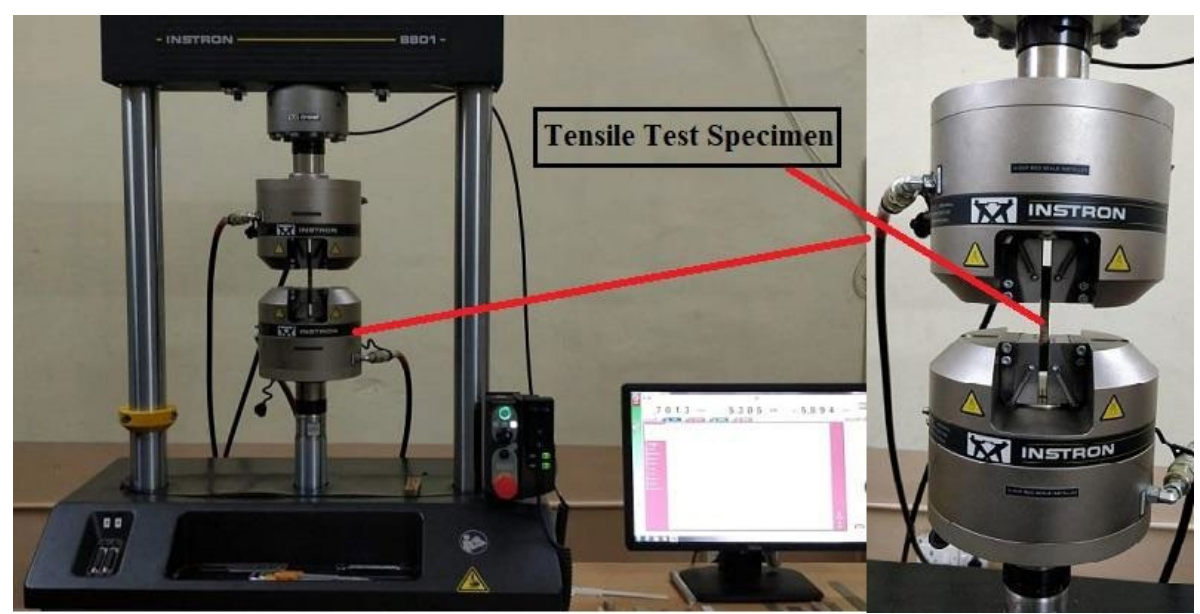

Figure 4. Tensile test setup on Instron (Model no: 8801).

\section{Microstructural Studies}

The samples were polished on a surface grinding machine and then mechanically ground polished with 1/0, 2/0, 3/0, and 4/0 grade papers, followed by a disc polishing machine using diamond paste as an abrasive medium. To ensure a mirror-like image was obtained for revealing the microstructure, samples were etched in $2 \%$ nital solution, followed by cleaning with deionised water, dipped in a solution of deionised water and dried. An inverted optical microscope (Leica DMILM) was used for microstructural characterisation. The composition of the fusion zone was examined using an energy-dispersive $\mathrm{x}$-ray spectroscope (EDS) linked to a scanning electron microscope (SEM) with magnifications of $6 \times$ to $600000 \times$ and SE, BSE, CCD detectors. Heat input can calculate by using the following formula:

$$
\text { Heat input }=\frac{0.9 \times I \times V \times 60}{1000 \times S}
$$

where, $V$ is arc voltage, $I$ is arc current, $S$ is welding speed and 0.9 is the arc efficiency [33].

\section{RESULTS AND DISCUSSION}

\section{Effects of Flux and Duplex Flux Coating on Weldments Mechanical Properties}

The room temperature tensile impact strengths result without flux coating is shown in Table 3 . The most outstanding tensile results (an average of three without coating) achieved about $480.286 \mathrm{MPa}$ at process parameters of $220 \mathrm{~A}, 16.2 \mathrm{~V}$, and $120 \mathrm{~mm} / \mathrm{min}$. During the procedure, it has been observed that tensile strength without flux coating of GTWA was nearer to the parent material $453 \mathrm{MPa}$. The improved tensile strength could be described because of the fine grain structure in the weld zone after-effects of re-melting and non-uniform cooling of the weld pool at room temperature, as shown in Figure 5. Likewise, tensile strength and impact strengths without flux coated weldments increased with an increase in current. Figure 6 shows that SEM/EDAX consequences without flux coating helped GTWA not dominating alloying components rather than $\mathrm{C}, \mathrm{O}$, and $\mathrm{Fe}$. The microhardness profiles measured with an average of three(locations) without flux coating weldments are better at $286 \mathrm{VH}$ at process parameters of $200 \mathrm{~A}, 16.2 \mathrm{~V}$, and $120 \mathrm{~mm} / \mathrm{min}$. It was far higher 
than the parent zone, at $170 \mathrm{HV}$. The microstructure outcomes likewise upheld the above results. The structure contained non-homogeneous all through the weld zone, similar effects by Sakthivel et al. [32].

Table 3. Experimental conditions for TIG welding process without flux coating.

\begin{tabular}{lccccccc}
\hline $\begin{array}{l}\text { Current } \\
(\mathrm{A})\end{array}$ & $\begin{array}{c}\text { Voltage } \\
(\mathrm{V})\end{array}$ & $\begin{array}{c}\text { Tensile strength } \\
(\mathrm{MPa})\end{array}$ & $\begin{array}{c}\text { Impact energy } \\
\left(\mathrm{J} / \mathrm{mm}^{2}\right)\end{array}$ & $\begin{array}{c}\text { Heat input } \\
(\mathrm{kJ} / \mathrm{mm})\end{array}$ & \multicolumn{3}{c}{ Microhardness $(\mathrm{HV})$} \\
\hline 160 & 14.8 & 462.63 & 1.281 & 1.065 & 214 & 176 & 176 \\
180 & 14.9 & 471.68 & 1.658 & 1.206 & 218 & 211 & 177 \\
200 & 14.7 & 474.35 & 1.906 & 1.323 & 232 & 210 & 183 \\
220 & 16.2 & 480.28 & 1.962 & 1.603 & 243 & 193 & 189 \\
\hline
\end{tabular}

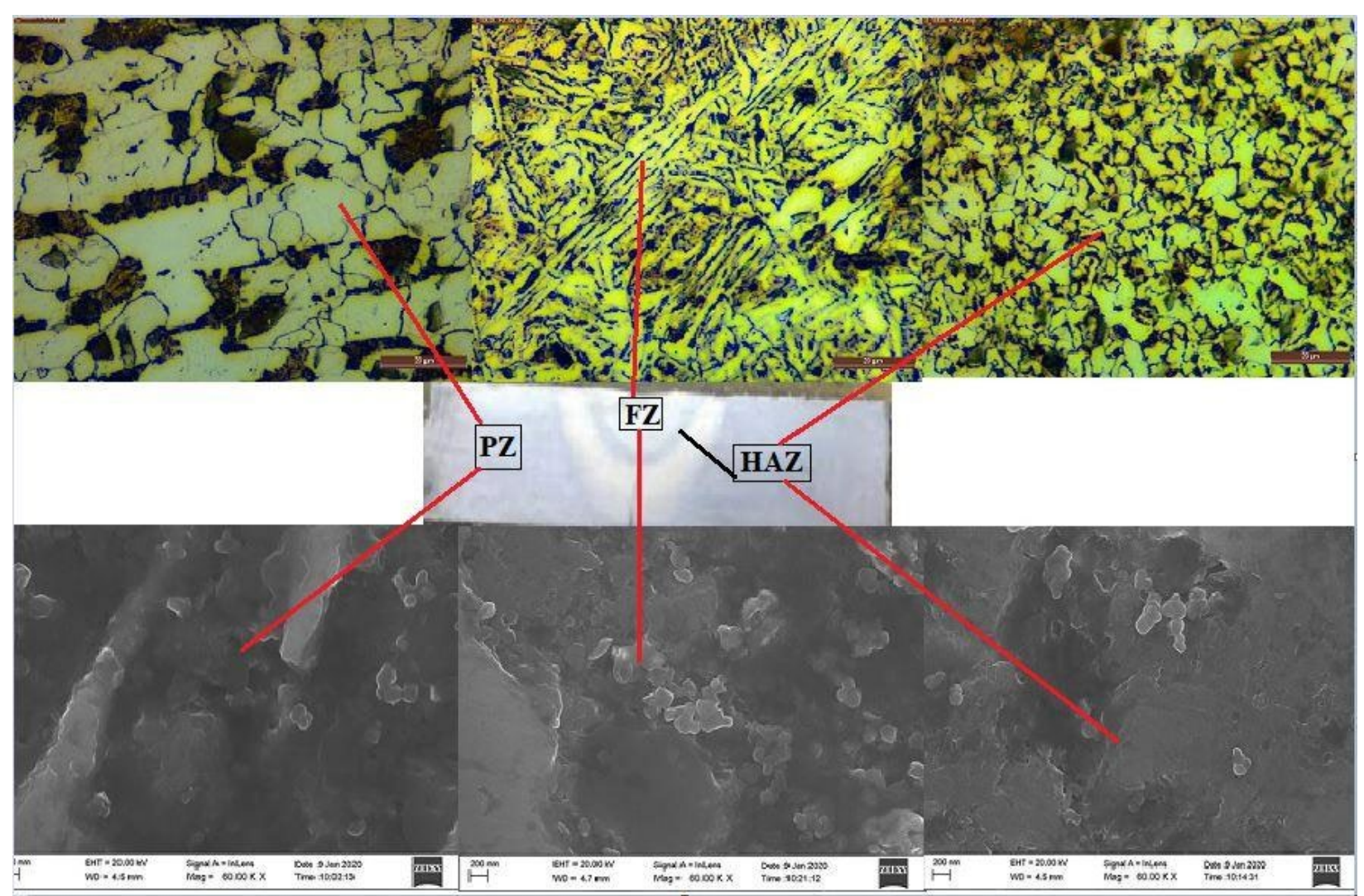

Figure 5. Fine grain structure and medium coarse grain structure and coarse grain structure in FZ, HAZ, PZ with optical and SEM results.
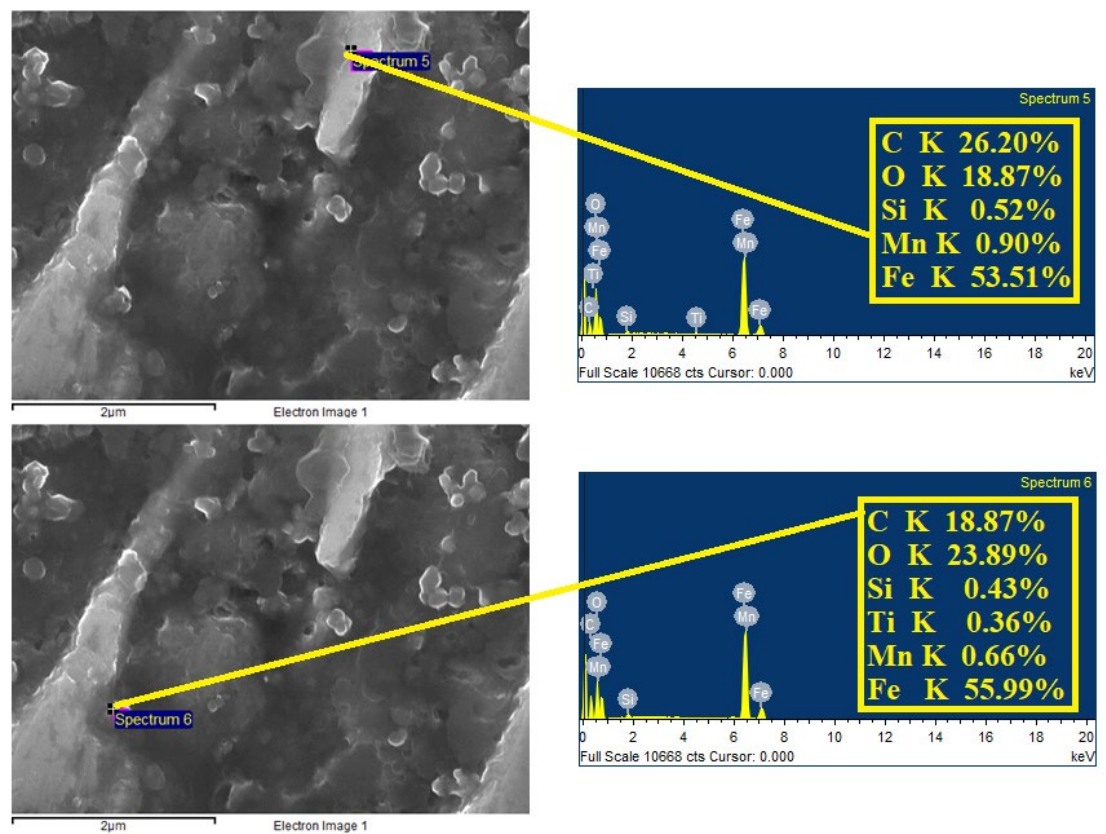

Figure 6. SEM-EDX results of fusion zone and parent zone without flux coating weldments. 
The author also revealed that an equiaxed grain structure would lead to higher hardness without a flux-assisted fusion zone. Charpy v-notch results speak to the fact that TIG weldments without flux coated weldments impact strength was $1.967 \mathrm{~J} / \mathrm{mm}^{2}$ at the welding parameters of $220 \mathrm{~A}, 16 \mathrm{~V}$, and $200 \mathrm{~mm} / \mathrm{min}$ welding speed. The improvement in toughness expanded with the current. This is expected higher current leads to higher heat inputs, bringing about an upgrade in grain refinement in the fusion zone and weld joints not gone through complete rupture, and somewhat broken at the notched zones [33].

\section{Effect of $\mathrm{MoO}_{3}, \mathrm{~V}_{2} \mathrm{O}_{5}$ Flux Coatings and $\mathrm{MoO}_{3}$ and $\mathrm{V}_{2} \mathrm{O}_{5}$ Duplex Flux Coating on Tensile and Impact Strengths}

With the $\mathrm{MoO}_{3}, \mathrm{~V}_{2} \mathrm{O}_{5}$, flux, $\mathrm{MoO}_{3}$, and $\mathrm{V}_{2} \mathrm{O}_{5}$ duplex flux assisted $\mathrm{AH} 36$ steel TIG weldments, tensile tests and impact strength investigations were carried out. In the experimental trials, the break suggested that it was experienced in the parent zone. The tensile characteristics and impact strength of $\mathrm{MoO}_{3}, \mathrm{~V}_{2} \mathrm{O}_{5}$, flux, and $\mathrm{MoO}_{3}$ and $\mathrm{V}_{2} \mathrm{O}_{5}$ duplex flux triggered TIG weldments of AH36 steel are shown in Table 4. It was discovered that with 220 A current and $120 \mathrm{~mm} / \mathrm{min}$ welding speed, $\mathrm{MoO}_{3}$ and $\mathrm{V}_{2} \mathrm{O}_{3}$ duplex flux coated weldments achieve a tensile strength of $602 \mathrm{MPa}$. At the similar process parameters, the flux $\mathrm{MoO}_{3}$ coating weldments was $506 \mathrm{MPa}$, and $\mathrm{V}_{2} \mathrm{O}_{5}$ flux coating was $535 \mathrm{MPa}$. Notwithstanding that, it was observed that these were higher than the conventional TIG weldments results. It was also noticed that as current increases, the tractable outcomes likewise tensile and impact strength results increased relatively. Figure 7 reveals the stress-strain behaviour of duplex $\left(\mathrm{MoO}_{3}+\mathrm{V}_{2} \mathrm{O}_{5}\right)$ flux coated weldment at 220 A. In duplex coating weldments, the effect impact strength acquired $1.881 \mathrm{~J} / \mathrm{mm}^{2}$ higher at $220 \mathrm{~A}, 14.2 \mathrm{~V}$, and $120 \mathrm{~mm} / \mathrm{min}$. It was seen those comparative outcomes appeared by individual $\mathrm{MoO}_{3}, \mathrm{~V}_{2} \mathrm{O}_{5}$ flux, and without flux coating, i.e., $1.623 \mathrm{~J} / \mathrm{mm}^{2}, 1.865 \mathrm{~J} / \mathrm{mm}^{2}$, and $1.96 \mathrm{~J} / \mathrm{mm}^{2}$; where Vasanthraja reported the close examinations [34]. The SEM/EDAX results show that in Figure 8 and Figure 9. The $\mathrm{MoO}_{3}$ had alloying wt.\% at 33.81\%, which may drive high tensile and impact strength, and the V wt.\% in fusion zone alloying of $\mathrm{V}_{2} \mathrm{O}_{5}$ flux had seen that $22.16 \%$ to $24.14 \%$, which results in the highest tensile and impact strengths of $\mathrm{V}_{2} \mathrm{O}_{5}$ flux coated weldments. For $\mathrm{MoO}_{3}$ and $\mathrm{V}_{2} \mathrm{O}_{5}$ duplex flux coating in Figure 10, there is evidence that a higher amount of $\mathrm{V}$ at $11.74 \%$ to $21.46 \%$ and Mo weight is about $9.26 \%$ to $15.26 \%$ in the fusion zone; due to this higher tensile and impact strength were expected.

Table 4. Experimental conditions for A-TIG welding process $\mathrm{MoO}_{3}$ flux coating.

\begin{tabular}{|c|c|c|c|c|c|c|c|c|}
\hline \multirow{2}{*}{ Type of flux } & \multirow{2}{*}{$\begin{array}{l}\text { Current } \\
\text { (A) }\end{array}$} & \multirow{2}{*}{$\begin{array}{l}\text { Voltage } \\
\text { (V) }\end{array}$} & \multirow{2}{*}{$\begin{array}{l}\text { Tensile strength } \\
(\mathrm{MPa})\end{array}$} & \multirow{2}{*}{$\begin{array}{l}\text { Impact energy } \\
\left(\mathrm{J} / \mathrm{mm}^{2}\right)\end{array}$} & \multirow{2}{*}{$\begin{array}{l}\text { Heat input } \\
(\mathrm{kJ} / \mathrm{mm})\end{array}$} & \multicolumn{3}{|c|}{ Microhardness (HV) } \\
\hline & & & & & & FZ & HAZ & $\mathrm{PZ}$ \\
\hline \multirow{4}{*}{$\begin{array}{l}\mathrm{MoO}_{3} \\
1 \mathrm{~mm} \text { thick } \\
\text { coating }\end{array}$} & 160 & 12.9 & 486.62 & 0.968 & 1.000 & 267 & 220 & 188 \\
\hline & 180 & 13.9 & 492.10 & 0.985 & 1.044 & 270 & 221 & 196 \\
\hline & 200 & 14.4 & 498.89 & 1.023 & 1.296 & 272 & 197 & 176 \\
\hline & 220 & 14.5 & 506.08 & 1.623 & 1.435 & 286 & 256 & 243 \\
\hline \multirow{4}{*}{$\begin{array}{l}\mathrm{V}_{2} \mathrm{O}_{5} \\
1 \mathrm{~mm} \text { thick } \\
\text { coating }\end{array}$} & 160 & 12.6 & 483.61 & 1.281 & 0.970 & 246 & 211 & 176 \\
\hline & 180 & 13.4 & 494.12 & 1.505 & 1.085 & 254 & 215 & 185 \\
\hline & 200 & 13.9 & 517.51 & 1.687 & 1.252 & 273 & 208 & 185 \\
\hline & 220 & 16.6 & 535.85 & 1.865 & 1.643 & 284 & 270 & 189 \\
\hline $\mathrm{MoO}_{3}+\mathrm{V}_{2} \mathrm{O}_{5}$ each & 160 & 15.9 & 526.25 & 1.156 & 1.574 & 228 & 221 & 189 \\
\hline $0.5+0.5 \mathrm{~mm}$ thick & 180 & 15.6 & 540.84 & 1.375 & 1.404 & 243 & 218 & 198 \\
\hline duplex flux & 200 & 15.3 & 575.42 & 1.156 & 1.239 & 265 & 260 & 229 \\
\hline coating & 220 & 13.9 & 602.71 & 1.881 & 1.000 & 297 & 217 & 182 \\
\hline
\end{tabular}

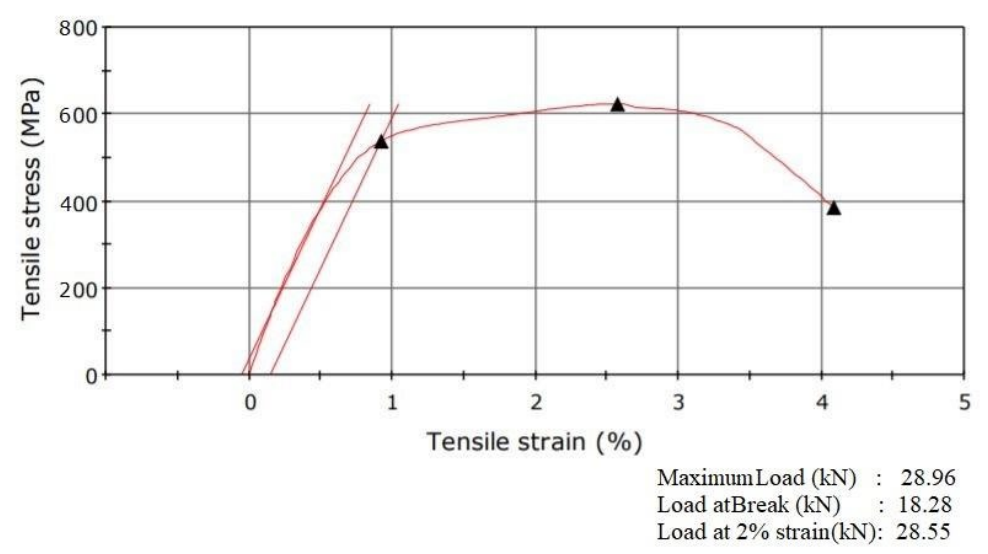

Figure 7. Stress-strain curve of $\mathrm{MoO}_{3}+\mathrm{V}_{2} \mathrm{O}_{5}$ duplex flux coated weldment at $220 \mathrm{~A}$. 

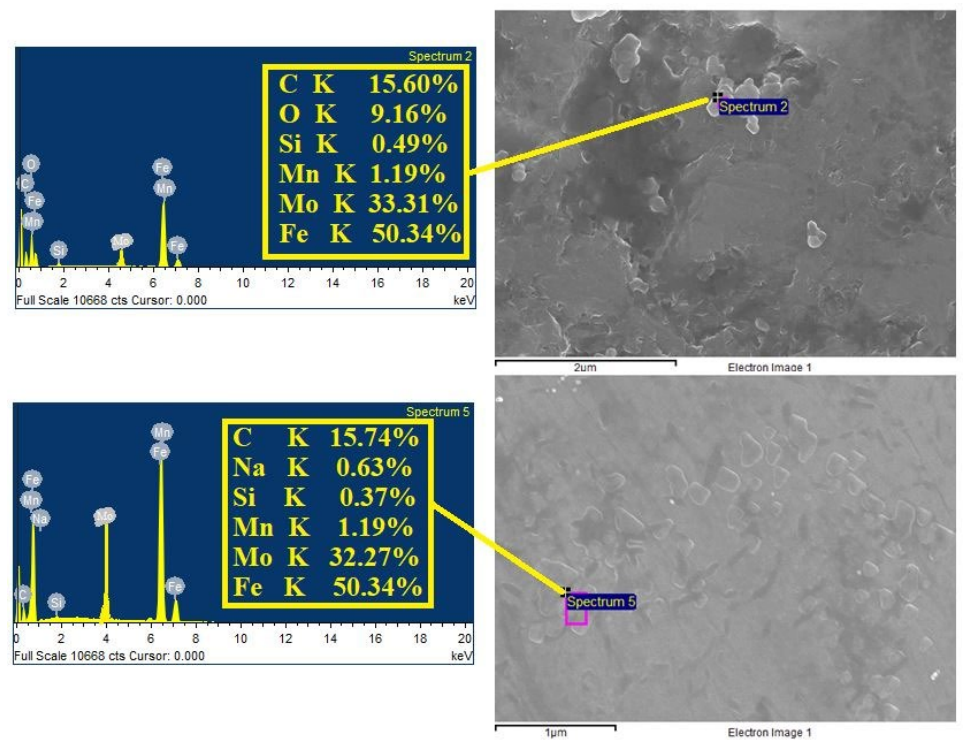

Figure 8. SEM-EDS results of fusion with $\mathrm{MoO}_{3}$ flux coating.
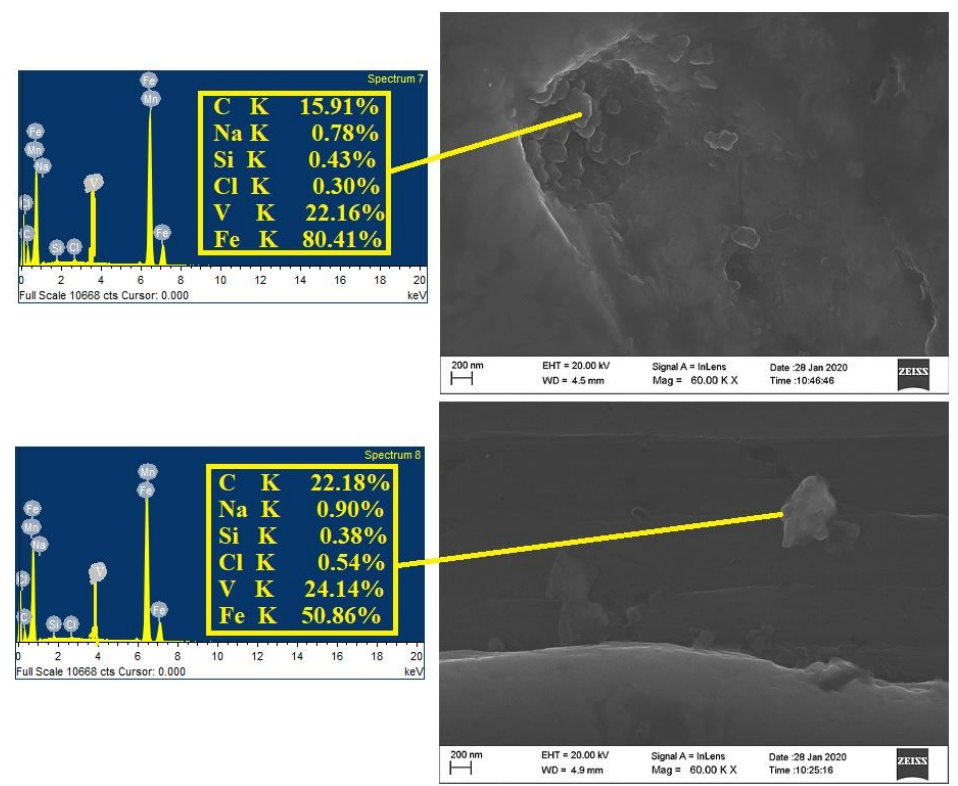

Figure 9. SEM-EDS results of fusion with $\mathrm{V}_{2} \mathrm{O}_{5}$ flux coating.

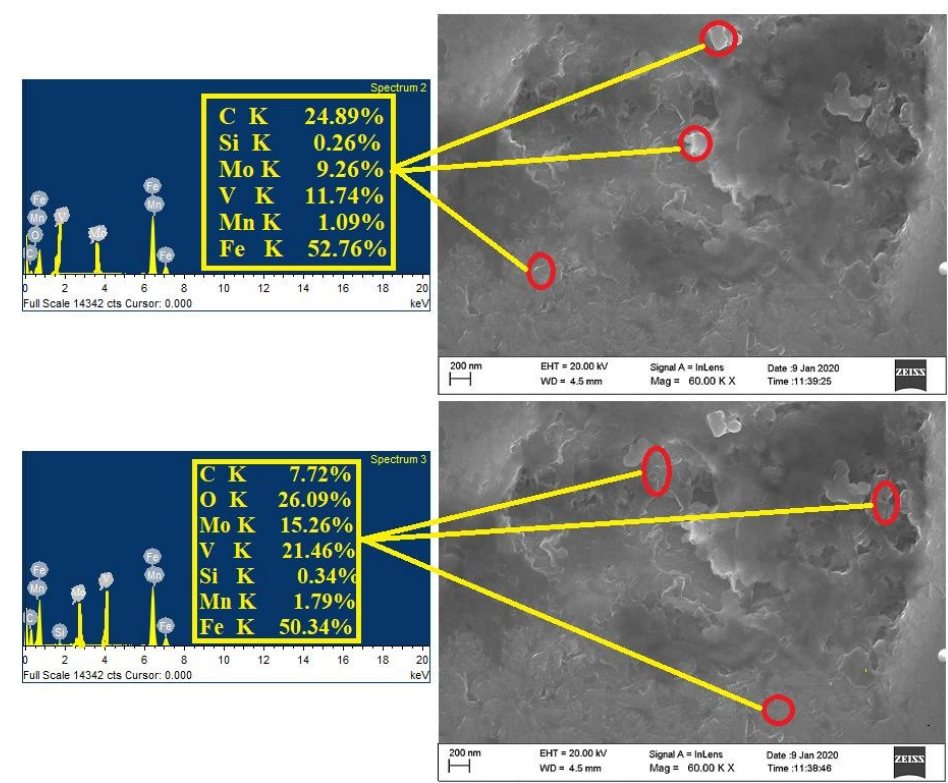

Figure 10. SEM-EDS results of fusion with $\mathrm{MoO}_{3}$ and $\mathrm{V}_{2} \mathrm{O}_{5}$ duplex flux coating. 


\section{Effect of Flux and Duplex Flux on Weld Bead Dimension}

From the trial results, different states of TIG and activated flux TIG weldments were delivered, as indicated in Figure 11. It was observed clearly; those TIG weldments are far not the same as A-TIG weldments. The higher weld deep penetration to weld joint width proportion is evidence of enhanced energy density of heat magnitude. Thereupon, the large degree of heat energy concentration throughout the TIG welding process was concluded by Natesan et al. [35] and Shyu et al. [36]. This resulted in electric arc constriction because activated flux coating was the primary reason for enlarging the weld depth penetration and lesser weld joint width in the current research. A more comprehensive weld joint width and small depth weld pool resulted without flux coating AH36 steel weldments (as shown in Figure 11), with a low aspect ratio(D/W) of about 0.315 . Firstly, it noticed a higher aspect ratio of about 1.355 and a deeper narrow weld pool obtained with $\mathrm{MoO}_{3}$ and $\mathrm{V}_{2} \mathrm{O}_{5}$ duplex flux due to the reverse Marangoni effect and higher energy used for penetration depth. Secondly, $\mathrm{V}_{2} \mathrm{O}_{5}$ individually produced a 1.049 aspect ratio(D/W). Finally, $\mathrm{MoO}_{3}$ independently achieved a 0.734 aspect ratio(D/W), as presented in Table 5 .

Figure 12 shows the variations in width, depth, and aspect ratios, that demonstrates how the depth of the weld bead reduces linearly as the flux type changes. Weldments without flux coating had a wider weld width, while $\mathrm{MoO}_{3}$ and $\mathrm{V}_{2} \mathrm{O}_{5}$ and duplex flux weldments had a narrower weld width. With varying fluxes, however, weld depth of penetration and aspect ratios rise linearly. Without flux coating weldments, it was noted that they had a lower depth and aspect ratio, while $\mathrm{MoO}_{3}$ and $\mathrm{V}_{2} \mathrm{O}_{5}$ duplex flux coated weldments had a higher depth and aspect ratio.

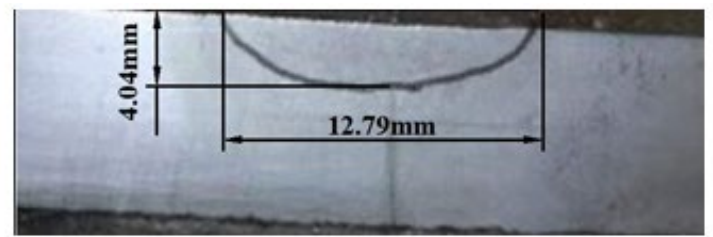

(a) without flux coating

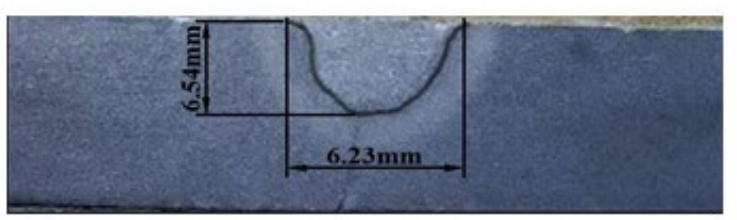

(c) $\mathrm{V}_{2} \mathrm{O}_{5}$ flux coating

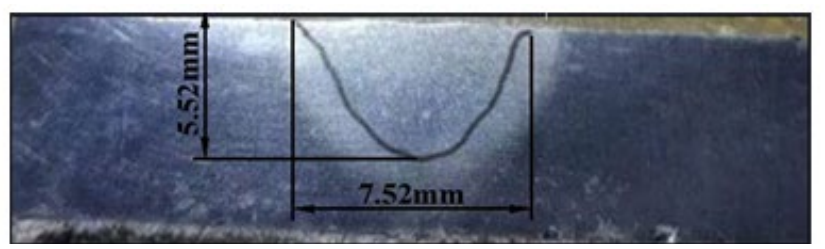

(b) $\mathrm{MoO}_{3}$ flux coating

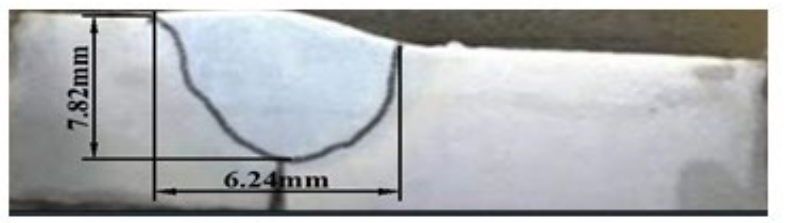

(b) $\mathrm{MoO}_{3}$ and $\mathrm{V}_{2} \mathrm{O}_{5}$ duplex flux coating

Figure 11. Weld bead variation with different fluxes.

Table 5. Width, depth, and D/W values at the current of $220 \mathrm{~A}$ and welding speed of $120 \mathrm{~mm} / \mathrm{min}$.

\begin{tabular}{lccc}
\hline Type of flux & Width, $\mathrm{W}(\mathrm{mm})$ & DOP, D $(\mathrm{mm})$ & D/W aspect ratio \\
\hline Without flux coating & 12.79 & 4.04 & 0.315 \\
$\mathrm{MoO}_{3}$ flux coating & 7.52 & 5.52 & 0.734 \\
$\mathrm{~V}_{2} \mathrm{O}_{5}$ flux coating & 6.23 & 6.54 & 1.049 \\
$\mathrm{MoO}_{3}$ and $\mathrm{V}_{2} \mathrm{O}_{5}$ Duplex flux & 6.24 & 7.82 & 1.355 \\
\hline
\end{tabular}

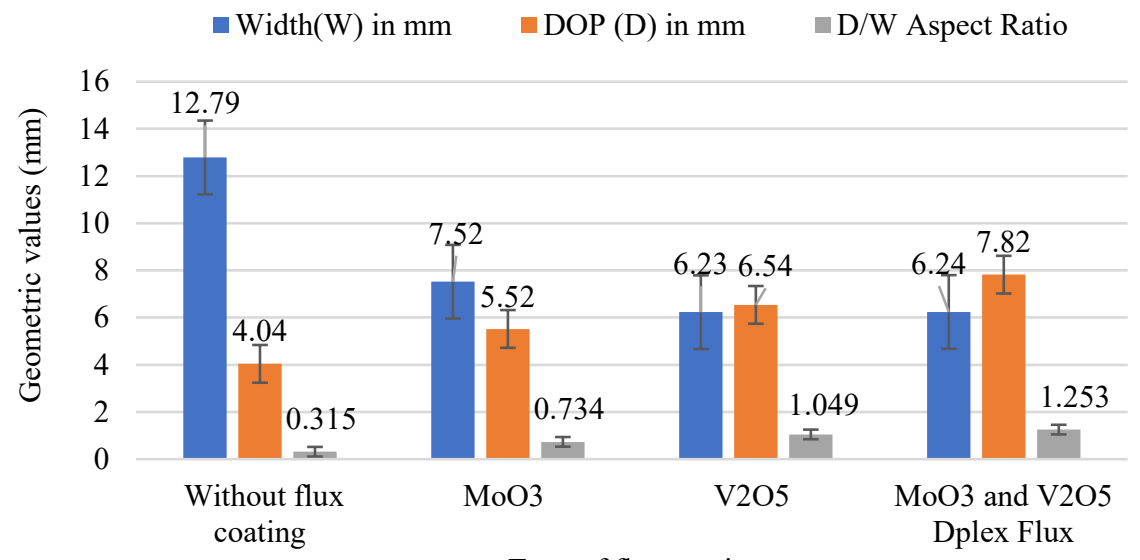

Type of flux coating

Figure 12. Width, depth, and D/W variations of different flux coatings. 


\section{Marangoni Mechanism in the Weld Pool}

In the TIG welding method, the Marangoni transfer way on the weld joint surface could fundamentally transform the heat conducted in the welding pool and change the weld bead geometry. Mostly, surface tension diminishes along with expanding temperature, pure materials, and alloys. Since a large temperature gradient survives in the welding joint surface between the centre below the weld joint's torch and side edges, a significant surface tension gradient is produced along the weld surface. In the weld pool mechanism, particularly under the arc, the surface tension was higher and very low at the edges of weld joint edges than that of the centre of the weld pool. Hence, molten metal flows from the joint centre to the edge of the joint. Heat transforms from the centre to the weld edges because of the mechanism, which yields large width and lower depth of weld joint. This mechanism is called Marangoni transformation. However, surface-active elements were used to reverse the Marangoni transformation, such as oxide, fluoride, and chloride components. When these elements are applied to the weld surface before welding results, the inflow of molten metal starts and surface tension gradient from edges to centre, this results in a large depth of weld joint and less weld joint width. This mechanism well knows for reverse Marangoni transformation happened particularly in stainless steel weld joints reported by Heiple and Roper [37]. Here how the surface tension and temperature gradient change from positive to negative detail are shown in Figure 13.

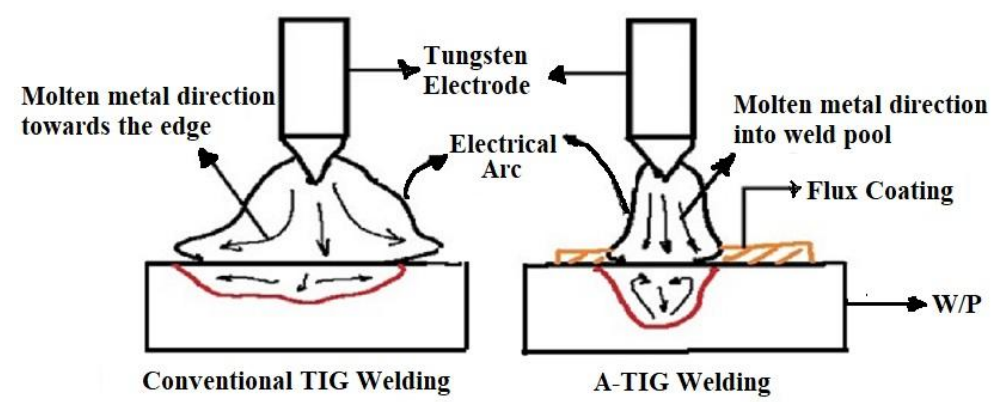

Figure 13. Marangoni and reverse Marangoni transformation mechanism.

\section{Effect of Fluxes Heat Input of Weld Pool}

The heat input can be calculated by using Eq. (2). In the current research study, welding parameters were used along with current, voltage, welding speed with straight polarity. In which welding speed was maintained constant, and the current varied from 160 A to 220 A uniformly. It was also noticed that the electric arc voltage without flux coating increased with current, and with flux coating, weldments voltage varies proportionally to the current in $\mathrm{MoO}_{3}$ and $\mathrm{V}_{2} \mathrm{O}_{5}$ flux coatings. TIG welding method with flux coating considerably growing the degree of the welding heat input [38]. This larger magnitude of heat input could enhance the maximum temperature of the weld material presented by Sandor and Dobranszky [39]. The primary reason for transforming the heat energy and concentration from the electrical arc to the workpiece material was oxide fluxes researched and reported by Leconte et al. [10]. The heat input with $\mathrm{MoO}_{3}$ and $\mathrm{V}_{2} \mathrm{O}_{5}$ is $1.435 \mathrm{~kJ} / \mathrm{mm}$ and $1.643 \mathrm{~kJ} / \mathrm{mm}$ respectively. Without flux coating, weldments attain $1.603 \mathrm{~kJ} / \mathrm{mm}$, higher than with flux coating weldments at the same process parameters. Activated flux TIG welding has a positive impact on increasing heat input in TIG welding. Until now, it is considered that the amount of weld molten metal is directly proportional to the heat-energy concentration due to this outcome, more accessible weld joint depth and less weld joint width achieved concluded by $\mathrm{Lu}$ et al. [40]. It was observed that the duplex of $\mathrm{MoO}_{3}$ and $\mathrm{V}_{2} \mathrm{O}_{5}$ flux coating heat input reduced with increasing current, and the voltage was inversely proportional to the current in all trials; this is due to electric arc constriction and stable arc mechanism. The foremost advantage in utilising oxide flux coatings in welding was to lower the heat energy appropriate for weld joint depth, as presented by Tseng and Hsu [41].

\section{Effect of Fluxes Heat Microhardness}

The AH36 flux coated and without flux coated samples were made for the micro Vickers hardness tests experiments. Most of the researcher's tests were carried out in FZ, HAZ, and PZ. The current study also followed the same at $2 \mathrm{~kg}$ load, $15 \mathrm{~s}$ dwell time, and $3 \mathrm{~mm}$ offset each indentation. The samples were prepared for microstructure observations, as used for Vickers Hardness Number (VHN) experiments. Higher microhardness was obtained for $\mathrm{MoO}_{3}$ and $\mathrm{V}_{2} \mathrm{O}_{5}$ duplex flux coat A-TIG weldments; about $297 \mathrm{HV}$ at process parameters of 220 A current and welding among all fluxes speed $120 \mathrm{~mm} / \mathrm{min}$. It was noticed that flux-coated weldments attained higher hardness than the conventional TIG weldments at the same process parameters in all trials. From Figure 14(a), microhardness values without flux coated weldments show more than the flux coating and duplex flux coating weldments. The $\mathrm{MoO}_{3}$ and $\mathrm{V}_{2} \mathrm{O}_{5}$ flux coating weldments show almost similar results in the fusion zone, i.e., $2297 \mathrm{Vh}$ and $286 \mathrm{VH}$, while $284 \mathrm{VH}$ in the fusion zone (FZ). Furthermore, all fusion zone microhardness with and without flux coating weldments are higher than the heat-affected zone and parent zone. This is due to one of the reasons that $\mathrm{Si}$ and $\mathrm{Zn}$ alloying elements in the weld pool from the flux usage. 


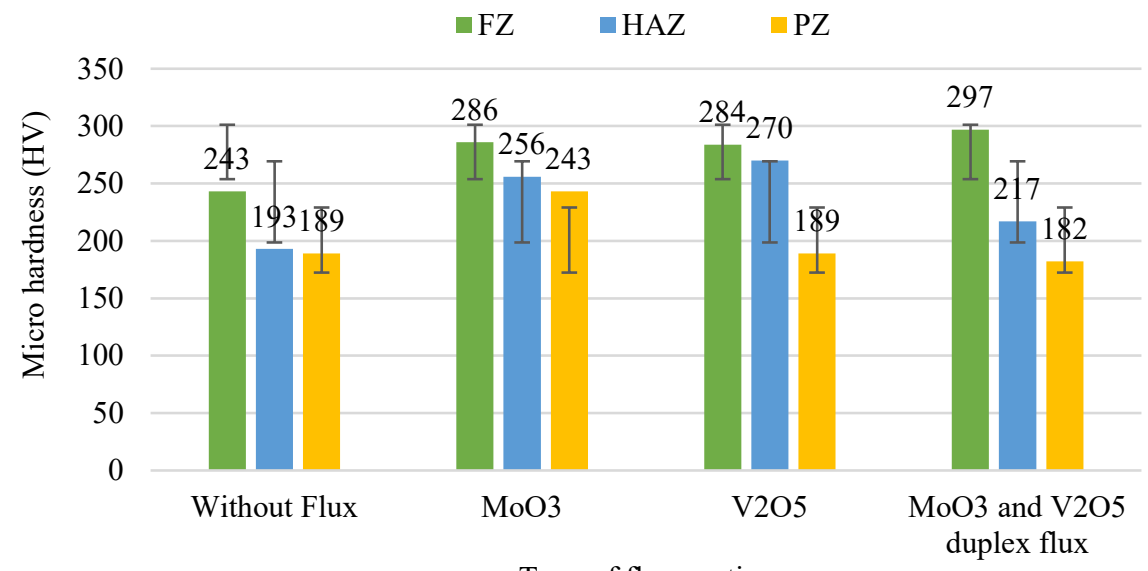

(a)

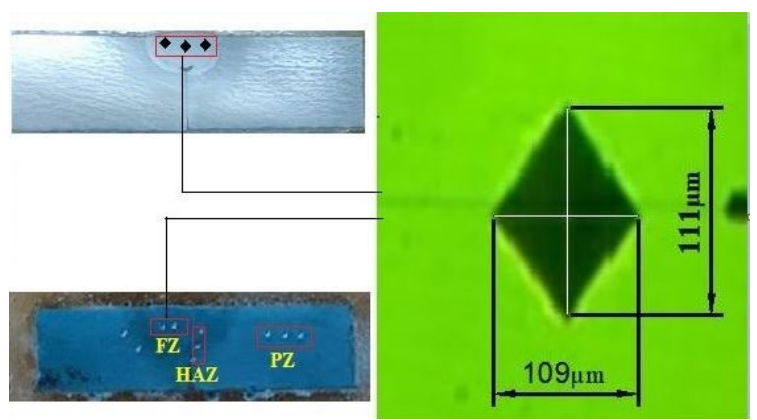

(b)

Figure 14. (a) Microhardness of FZ, HAZ, and PZ in the weldments (with and without flux coated and duplex flux), and (b) indentation with an average diagonal length of $110 \mu \mathrm{m}$ for duplex flux coating FZ.

\section{CONCLUSION}

In the current research, tests are conducted and investigated in detail on TIG welding with the application of oxide fluxes before welding two AH36 steel plates in the butt position. The fluxes used are $\mathrm{MoO}_{3}, \mathrm{~V}_{2} \mathrm{O}_{5}$, and $\mathrm{MoO}_{3}$, and $\mathrm{V}_{2} \mathrm{O}_{5}$ duplex flux. The significant outcomes attained are as follows:

i. High quality AH36 steel weldments was obtained using the TIG welding process with activated flux and duplex flux.

ii. Higher weld depth penetrations were obtained for duplex flux, $\mathrm{MoO}_{3}, \mathrm{~V}_{2} \mathrm{O}_{5}$ as $8.46 \mathrm{~mm}, 5.52 \mathrm{~mm}$, and $6.54 \mathrm{~mm}$, respectively and these were higher than the conventional TIG weld penetration, $4.04 \mathrm{~mm}$.

iii. The depth of weld penetration and aspect ratios of $\mathrm{MoO}_{3}, \mathrm{~V}_{2} \mathrm{O}_{5}$, and duplexes flux coating weldments increased proportionally than the conventional TIG weldments.

iv. The results noticed a significant increase in heat input due to the usage of oxide fluxes. The activated flux coating TIG welding process could enhance the electric arc voltage; the magnitude of heat input per unit length in a weld is also greatly enlarged. Hence, the delta-ferrite amount in weld region material could be enhanced.

v. The aspect ratio of weld joints is enhanced with A-TIG welding where the attained results for duplex flux is $1.355, \mathrm{MoO}_{3}$ flux is 0.734 , and $\mathrm{V}_{2} \mathrm{O}_{5}$ flux is 1.049 . These were higher compare with the conventional TIG welding method.

vi. The obtained mechanical properties of A-TIG weldments of AH36 are superior relative to the conventional TIG welding operation.

vii. Based on all flux's experimental trails, duplex flux was successfully used for welding AH36 steel $8 \mathrm{~mm}$ thick plates in the butt position at $220 \mathrm{~A}$ current and $120 \mathrm{~mm} / \mathrm{min}$ process parameters.

viii. Microstructure studies show that columnar structure and equiaxed in the fusion zone with oxide fluxes usage leads to superior mechanical properties than the conventional TIG welding.

\section{ACKNOWLEDGEMENT}

The authors are grateful to Indian Institute of Technology Madras, India, for allowing a platform for conducting experimental work need for the current research, Hindustan Shipyard Pvt Ltd (HSL), Visakhapatnam, India for sponsoring the raw material for research works, and GITAM University Visakhapatnam, India for their support for conducting experimental work. 


\section{REFERENCES}

[1] G. Malakondaiah. "Development of specialty low alloy steels," In International Conference on Metals and Alloys, Past, Present and Future," 2007, pp. 17.

[2] S. Mallik, BS. Minz, and B. Mishra, "Production of DMR 249A Steel at SAIL, Bokaro Steel Plant," Mater. Sci. Forum, 2012, vol. 710, p. 149-54, doi: 10.4028/www.scientific.net/MSF.710.149.

[3] K. Tseng, and K. Chuang, "Application of iron-based powders in tungsten inert gas welding for $17 \mathrm{Cr}-10 \mathrm{Ni}-2 \mathrm{Mo}$ alloys," Powder Technol., 2012, vol. 228, p. 36-46, doi: 10.1016/j.powtec.2012.04.047.

[4] K.H. Tseng, and K.L. Chen, "Comparisons between TiO2- and SiO2-flux assisted TIG welding processes," J. Nanosci. Nanotechnol., 2012, vol. 12, p. 6359-6367, doi: 10.1166/JNN.2012.6419.

[5] HY. Huang, SW. Shyu, KH. Tseng, and CP. Chou, "Study of the performance of stainless-steel A-TIG welds," J. Mater. Eng. Perform., 2007, vol. 17, no. 2, p. 193-201, doi: 10.1007/s11665-007-9139-7.

[6] Sridhar S.P "A study on the effect of different activating flux on A-TIG welding process of Incoloy 800H," J. Adv. Mater. Sci., vol. 2016; pp. 26-37, 2016, doi:https://doi.org/10.1515/adms-2016-0014.

[7] P.J. Modenesi, E.R. Apolinário, and I.M. Pereira, "TIG welding with single component flux," J. Mater. Process. Technol., vol. 99, no. 1-3, p. 260-265, 1998, doi: 10.1016/S0924-0136(99)00435-5.

[8] Q.M. Li et al., "Effect of activating flux arc shape and arc voltage in tungsten inert gas welding," Trans. Nonferrous Met. Soc. China, vol. 17, no. 3, p. 486-490, 2007, doi: 10.1016/S1003-6326(07)60120-4.

[9] H.Y. Huang et al., "Evaluation of TIG flux welding on the characteristics of stainless steel," Sci. Technol. Weld. Join. vol. 10, no. 5, p. 566-573, 2005, doi: 10.1179/174329305X48329.

[10] S. Leconte et al., "Effect of oxide fluxes on activation mechanisms of tungsten inert gas process," Sci. Technol. Weld. Join., vol. 11, no. 4, pp. 389-397, 2006, doi: 10.1179/174329306X129544.

[11] L. Liu and H. Sun, "Study of flux assisted TIG welding of magnesium alloy with SiC particles in flux," Mater. Res. Innov., vol. 12, no. 1, pp. 47-51, 2008, doi: 10.1179/143307508X270776.

[12] M. Marya and G.R. Edwards, "Chloride contributions in flux assisted GTA welding of magnesium alloys," Weld. J., vol. 81, no. 12, pp. 291-298, 2002.

[13] T.S. Chern, K.H. Tseng, and H.L. Tsai, "Study of the characteristics of duplex stainless steel activated tungsten inert gas welds," Mater. Des., vol. 32, no. 1, pp. 255-263, 2011, doi: 10.1016/j.matdes.2010.05.056.

[14] K. Devendranath Ramkumar et al., "Investigations on structure-property relationships of activated flux TIG weldments of super-duplex/austenitic stainless steels," Mater. Sci. Eng. A, vol. 638, pp. 60-68, 2015, doi: 10.1016/j.msea.2015.04.041.

[15] K.H. Tseng, and C.Y. Hsu, "Performance of activated TIG process in austenitic stainless-steel welds," J. Mater. Process Technol., vol. 211, no. 3, pp. 503-12, 2011, doi: 10.1016/j.jmatprotec.2010.11.003.

[16] G. Venkatesan et al., "Effect of ternary fluxes on depth of penetration in A-TIG Welding of AISI 409 ferritic stainless steel," Procedia Materials Science, vol. 5, pp. 2402-2410, 2014, doi: 10.1016/j.mspro.2014.07.485.

[17] H.Y. Huang et al., "Evaluation of TIG flux welding on the characteristics of stainless steel," Sci. Technol. Weld. Join., vol. 19, no. 5, pp. 566-573, 2005, doi: 10.1179/174329305X48329.

[18] K.H. Tseng and P.Y. Chen, "Effect of TiO2 crystalline phase on performance of flux assisted GTA welds," Mater. Manuf. Process, vol. 31, no. 3, pp. 359-365, 2016, doi: 10.1080/10426914.2015.1058952.

[19] S. Prajapati and K. Shah, "Experimental study on activated tungsten inert gas welding," Int. J. Adv. Res. Innov. Ideas Educ., vol. 2, no. 3, pp. 2555-2559, 2016.

[20] S. Nagaraju et al., "Optimisation of welding process parameters for 9Cr-1Mo steel using RSM and GA," Mater. Manuf. Process, vol. 31, no. 3, pp. 319-327, 2016, doi: 10.1080/10426914.2015.1025974.

[21] B.G. Paul and K.C. Ramesh Kumar, "Effect of single component and binary fluxes on the depth of penetration in a-TIG welding of Inconel alloy 800H austenitic stainless steel," Int. J. Adv. Eng. Glob. Technol., vol. 5, pp. 1791-1795, 2017.

[22] M. Jurica and Z. Kozuh, "Optimisation of the A-TIG welding for stainless steels," IOP Conf. Ser.: Mater. Sci. Eng., vol. 329 , pp. 1-9, 2018, doi: 10.1088/1757-899X/329/1/012012.

[23] A. Hdhibi et al., "Effect of single oxide fluxes on morphology and mechanical properties of ATIG on $316 \mathrm{~L}$ austenitic stainlesssteel welds," Eng. Technol. Appl. Sci. Res., vol. 8, no. 3, p. 3064-3072, 2018, doi: 10.48084/etasr.2097.

[24] E.Y. Salawu et al., "Investigation of production output for improvement," Int. J. Mech. Prod. Eng. Res. Dev., vol. 8, no. 1, pp. 915-922, 2018.

[25] S.A. Afolalu et al., "Impact of activated-flux tungsten inert gas (a-tig) welding on weld joint of a metal," IOP Conf. Ser.: Mater. Sci. Eng., vol. 640, no. 1, pp. 012064, 2019, doi: 10.1088/1757-899X/640/1/012064.

[26] P. Sharma and DK. Dwivedi, "Comparative study of activated flux-GTAW and multipass-GTAW dissimilar P92 steel-304H ASS joints,” Mater. Manuf. Process, vol. 34, no. 11, p. 1195-1204, 2019, doi: 10.1080/10426914.2019.1605175.

[27] S. Tathgir, DW. Rathod, and A. Batish, "A-TIG welding process for enhanced-penetration in Duplex stainless-steel: Effect of activated fluxes,” Mater. Manuf. Process, vol. 34, no. 15, pp. 1659-1670, 2019, doi: 10.1080/10426914.2019.1666990.

[28] K. Touileb et al., "Effects of A-TIG welding on weld shape, mechanical properties, and corrosion resistance of 430 ferritic stainless steel alloy," Metals (Basel), vol. 10, no. 3, pp. 1-17, 2020, doi: 10.3390/met10030404.

[29] H. Rana et al. "Augmentation of weld penetration by flux assisted TIG welding and its distinct variants for oxygen free copper," J. Mater. Process. Technol., vol. 10, pp. 138-151, 2021, doi: 10.1016/j.jmrt.2020.12.009.

[30] E. Ahmadi and A.R. Ebrahimi, "Welding of 316L austenitic stainless steel with activated tungsten inert gas process," J. Mater. Eng. Perform., vol. 24, pp. 1065-1071, 2015, doi: 10.1007/s11665-014-1336-6.

[31] B. Arivazhagan and M. Vasudevan, "A study of microstructure and mechanical properties of grade 91 steel A-TIG weld joint," J. Mater. Eng. Perform., vol. 22, no. 12, pp. 3708-3716, 2013, doi: 10.1007/s11665-013-0694-9.

[32] T. Sakthivel et al., "Comparison of creep rupture behaviour of type 316L(N) austenitic stainless-steel joints welded by TIG and activated TIG welding processes," Mater. Sci. Eng. A, vol. 528, no. 22-23, pp. 6971-6980, 2011, doi: 10.1016/j.msea.2011.05.052.

[33] P. Sharma and DK. Dwivedi, "Improving the strength-ductility synergy and impact toughness of dissimilar martensiticaustenitic steel joints by A-TIG welding with wire feed," Mater. Lett., vol. 285, 2021, doi: 10.1016/j.matlet.2020.129063. 
[34] P. Vasantharaja and M. Vasudevan, "Studies on A-TIG welding of low activation ferritic/martensitic (LAFM) steel," J. Nucl. Mater., vol. 421, pp. 117-123, 2012, doi: 10.1016/j.jnucmat.2011.11.062.

[35] K. Natesan et al., "Preliminary materials selection issues for the next generation nuclear plant reactor pressure vessel," Argonne National Laboratory, 2006, doi: 10.2172/925328.

[36] S.W. Shyu et al., "Study of the performance of stainless-steel A-TIG welds," J. Mater. Eng. Perform., vol. 17, no. 2, pp. 193201, 2008, doi: 10.1007/s11665-007-9139-7.

[37] C.R. Heiple and J.R. Roper, "Mechanism for minor element on GTA fusion zone geometry," Weld. J., Welding Research Supplement, pp. 97-102, 1982.

[38] J. Hilkes and V. Gross, "Welding CrMo steels for power generation and petrochemical applications - past, present, and future," Biul Instyt Spawalnictwa, vol. 2, p. 11-22, 2013.

[39] T. Sandor and J. Dobranszky, "The experiences of activated tungsten inert gas (A-TIG) welding applied on 1.4301 type stainless steel plates," Mater. Sci. Forum, vol. 537-538, p. 63-70, 2007, doi: 10.4028/www.scientific.net/MSF.537-538.63.

[40] S. Lu, H. Fujii, and K. Nogi, "Marangoni convection and weld shape variations in Ar-O2and Ar-CO2shielded GTA welding," Mater. Sci. Eng. C, vol. 380, pp. 290-297, 2004, doi: 10.1016/j.msea.2004.05.057.

[41] K.H. Tseng and C.Y. Hsu, "Performance of activated TIG process in austenitic stainless-steel welds," J. Mater. Process Technol., vol. 211, no. 3, pp. 503-512, 2011, doi: 10.1016/j.jmatprotec.2010.11.003. 